\title{
Oropharyngeal Cancer Pathologic Regional Lymph Nodes TNM Finding v7
}

National Cancer Institute

\section{Source}

National Cancer Institute. Oropharyngeal Cancer Pathologic Regional Lymph Nodes

TNM Finding v7. NCI Thesaurus. Code C89007.

A pathologic finding about one or more characteristics of oropharyngeal cancer, following the rules of the TNM AJCC V7 classification system as they pertain to staging of regional lymph nodes. Metastases at level VII are considered regional lymph node metastases. (from AJCC 7th Ed.) 